\title{
Severity of Citrus tristeza virus Isolates from Texas
}

\author{
C. M. Herron and T. E. Mirkov, Department of Plant Pathology and Microbiology, Texas A\&M University System \\ Agricultural Experiment Station, and N. Solís-Gracia, C. J. Kahlke, M. Skaria, and J. V. da Graça, Texas A\&M \\ University-Kingsville Citrus Center, Weslaco 78596
}

\begin{abstract}
Herron, C. M., Mirkov, T. E., Solís-Gracia, N., Kahlke, C. J., Skaria, M., and da Graça, J. V. 2005. Severity of Citrus tristeza virus isolates from Texas. Plant Dis. 89:575-580.

Citrus tristeza virus (CTV) isolates collected from the Lower Rio Grande Valley in south Texas and east Texas were characterized using citrus indicators and molecular methods. The citrus indicators were Mexican lime (Citrus aurantifolia), sour orange (C. aurantium), sweet orange (C. sinensis) grafted to sour orange, Duncan grapefruit $(C . \times$ paradisi $)$, and Madam Vinous sweet orange, with some CTV isolates additionally indexed using the Texas commercial grapefruit cvs. Rio Red and Star Ruby, and Marrs and N-33 sweet orange. Severity ratings used 11 biotype groups or cumulative mean relative indices. Molecular characterization was carried out using poly- and monoclonal antibodies, seven strain-specific probes and single-stranded conformational polymorphism, and all were based on the CTV major coat protein or gene. All Texas CTV isolates produced vein clearing symptoms on inoculated Mexican lime plants. Over half of the CTV isolates tested were placed in biotype groups IX and X (causing decline of sweet orange on sour orange, seedling yellows on sour orange and grapefruit seedlings, and stem pitting of grapefruit or sweet orange), and one isolate was in biotype I (mild).
\end{abstract}

Citrus tristeza virus (CTV) is an aphidtransmitted closterovirus with flexuous filamentous particles having a very large (approximately $20 \mathrm{~kb}$ ) single-stranded, positive-sense RNA (ssRNA) genome (4). Observations and molecular studies indicate that the CTV occurring in one tree is usually a mixture of genotypes and fits the concept of a virus quasispecies (9). CTV is disseminated into new citrus-growing areas mainly through movement of CTVinfected nursery material (32). Aphid dissemination is an important route of transmission, with the most efficient CTV vector being Toxoptera citricida Kirkaldy, the brown citrus aphid (BrCA) (4).

Many CTV isolates have been described and characterized $(12,37)$. The isolates vary in their ability to produce symptoms in citrus; and the symptoms produced can alter after passage through various aphids or plants. Generally, isolates are characterized biologically according to symptoms induced in a standard panel of citrus indicator plants under greenhouse conditions and, based upon symptoms expressed, can

Corresponding author: J. V. da Graça

E-mail: j-dagraca@tamu.edu

This work was funded in part by the USDA CSREES Special Grants Program for Citrus Tristeza Research (2000-34399-9641 to J. V. da Graça \& C. M. Herron and 2002-34399-12399 to T. E. Mirkov).

Accepted for publication 2 February 2005.

DOI: 10.1094/PD-89-0575

(C) 2005 The American Phytopathological Society be assessed according to two complementary methods. The first applies an economic weighting to the severity score (12) and the second places the CTV reaction in one of 11 reaction type groups $(12,34)$, in which the higher the score or biotype, the more severe the CTV isolate. Mild CTV isolates, those considered as causing disease symptoms only in Mexican lime (Citrus aurantifolia) (biotype I), cause very little or no damage to commercial citrus and may be beneficial because they protect against severe CTV damage by crossprotection.

The BrCA was introduced into South America early last century, and severe epidemics of CTV have occurred in the wake of BrCA movement into various citrus-growing regions of Argentina, Brazil, Paraguay, and Uruguay (38). Current interest in the CTV status of Texas citrus has been heightened by the recent northern movement of the BrCA into Florida (14) and southern Mexico (23).

The majority of the commercially grown citrus in Texas is red grapefruit $(C . \times$ paradisi) on sour orange (C. aurantium) rootstock. In red grapefruit, nondamaging CTV isolates spread slowly (5), and pigmented grapefruit also is reported to be more sensitive to CTV stem pitting symptoms (20). Sour orange rootstock makes the plants susceptible to CTV decline. Once the BrCA arrives in Texas, it is anticipated that CTV already present in the citrus will be temporally and spatially distributed to the majority of trees.

Although there currently are no economic losses being caused by CTV in Texas, the virus was first detected in south
Texas in 1954 in Meyer lemon (C. meyeri, 29) and satsuma (C. unshiu; 28) by indexing on Mexican lime. Shortly thereafter, 14 infected trees in a collection of imported trees and in two locally grown Valencia sweet orange $(C$. sinensis; 27$)$ trees were found. CTV infections in Meyer lemon and grapefruit also were found in the upper Gulf Coast area of east Texas (19). A survey in 1984 did not detect any CTV using enzyme-linked immunosorbent assay (ELISA) in commercial plantings, but did find a few infected dooryard trees (8). In an extensive survey of over 11,000 trees throughout Texas over a 10-year period, CTV incidences of $1.1 \%$ in the Lower Rio Grande Valley and $18 \%$ in east Texas were determined (45). A legislated Texas budwood certification program has been established to ensure that nurseries propagate only virus-free trees $(16,44)$.

The aims of this study were to biologically characterize the CTV isolates collected in the various regions of Texas before the BrCA arrives. Additionally, various available rapid methods were assessed to characterize the CTV isolates and the results were compared with the severity based upon biological indexing. Both of these aims are congruent with the aim to develop a sound CTV management strategy for the Texas certification program.

\section{MATERIALS AND METHODS}

Indexing on citrus. CTV isolates collected from field sources at various times since the 1970 s were maintained in a greenhouse on various citrus hosts. Donor buds or stem bark pieces (two to four per seedling) were graft inoculated in quadruplet to citrus indicators in June 1997 (35; experiment 1). Five citrus indicator plants were used: Mexican lime, Duncan grapefruit, Pineapple sweet orange grafted to sour orange, sour orange seedlings, and Madam Vinous sweet orange seedlings. In addition, Rio Red and Star Ruby grapefruit and sweet orange navel cvs. Marrs and N33 , all grafted on sour orange rootstock, were used as additional indicators for some of the CTV isolates. Plants were kept in the cool $\left(27\right.$ to $30^{\circ} \mathrm{C}$ maxima, 18 to $21^{\circ} \mathrm{C}$ minima) indexing facility. Visual assessments of symptoms were made periodically over a 2-year period according to methods detailed by Garnsey et al. (12). A second biological indexing (experiment 2) was conducted in the same facilities with plants inoculated in August 2001. Six reference CTV isolates (B2, B4, B5, B6, B28, 
and B384) from the Citrus Exotic Pathogen Collection (11) maintained in the quarantine facilities at the United States Department of Agriculture-Agricultural Research Service (USDA-ARS) Beltsville Agricultural Research Center, MD (BARC), were obtained under USDA permit no. 46874. Buds were graft inoculated onto Pineapple sweet orange seedlings in the Texas A\&M University-Kingsville Citrus Center's indexing facility. These six reference CTV isolates then were compared in the evaluation with selected Texas CTV isolates (H11, H29, H33, and H41). The symptoms were assessed for 12 months. For all plants, ELISA tests were used to detect the extent of CTV infection.

RNA-blot analyses. Nucleic acids were extracted from leaf tissue of each test using a modified double phenol/chloroform extraction method in extraction buffer $(0.1$ $\mathrm{M} \mathrm{NaCl}, 0.01 \mathrm{M}$ Tris-HCl, pH 7.5, $1 \mathrm{mM}$ EDTA, and $1 \%$ sodium dodecyl sulfate; 43) and ethanol precipitation. After centrifugation, pellets were resuspended in sterile ultrapure water. Total RNA was precipitated by adding two volumes of $7 \mathrm{M}$ $\mathrm{LiCl}$ and incubated for $12 \mathrm{~h}$ at $4^{\circ} \mathrm{C}$, after which pellets were obtained by centrifugation, washed with $70 \%$ ethanol, and resuspended in sterile ultrapure water. Total RNA was quantified by UV spectrophotometry. Denatured total RNA (3 $\mu \mathrm{g}$ ) was checked for integrity by electrophoresis through $1 \%$ agarose with Tris-borateEDTA (TBE) buffer ( $89 \mathrm{mM}$ Tris-borate, pH 8.0, 2 mM EDTA). For size analyses and hybridization, formamide and heattreated denatured RNA $(10 \mu \mathrm{g})$ was elecand transferred to nylon membranes according to methods cited before (43). Hying to Church and Gilbert (6) with a ${ }^{32} \mathrm{P}-$ labeled dCTP DNA probe derived from the $3^{\prime}$ end of the CTV SY568 genome, made using a DNA labeling kit for random primers and the supplier's instructions (GibcoBRL Life Technologies, Gaithersburg, MD). trophoresed in formaldehyde-1.6\% agarose bridization was performed at $65^{\circ} \mathrm{C}$ accord-

ELISA. Double antibody sandwichindirect (DAS-I)-ELISA was performed using two CTV polyclonal antisera and methods cited before $(10,33)$. The data represent three separate duplicated experiments with uninoculated, CTVinfected citrus controls and extraction buffer controls in each test.

Tissue immunoblot. Reaction of the CTV source plants to CTV monoclonal antibodies (MAbs) monoclonal antibody13 (MCA-13) was tested and assessed as a tissue immunoblot (Nokomis Corp., Altamonte Springs, FL). MCA-13 was raised against a decline-inducing CTV isolate and has been reported to react with isolates inducing decline, seedling yellows, and stem-pitting, but not with mild isolates (32). Four young stems were taken from each test plant and the cut stem end of each was blotted onto nitrocellulose paper. The paper was air dried and sent to Nokomis Corp. for assessment. Uninoculated citrus plants were included as test samples.

cDNA production. CTV coat protein (CP) gene (CPG)-specific cDNA was produced by reverse-transcription polymerase chain reaction (RT-PCR) using CTV specific primers. The sequence and approximate position of these primers with respect to the CTV CPG are given in Figure 1. One-step RT-PCR contained $15 \mu \mathrm{l}$ of a double-stranded (ds)RNA-enriched total RNA sample from each Texas CTV citrus source. The RNA was heated at $70^{\circ} \mathrm{C}$ for 5 min, then placed on ice. The reaction mix final volume was $50 \mu \mathrm{l}$, which contained 100 pmole each of the primers $\mathrm{CN} 405$ and $\mathrm{CN} 408 ; 10 \mathrm{mM}$ Tris- $\mathrm{HCl}, \mathrm{pH} \mathrm{8.3}$, at $25^{\circ} \mathrm{C} ; 50 \mathrm{mM} \mathrm{KCl} ; 2.5 \mathrm{mM} \mathrm{MgCl}$; 10 $\mathrm{mM}$ dithiothreitol (DTT); $0.2 \mathrm{mM}$ each dATP, dCTP, dGTP, and dTTP; $5 \mathrm{U}$ of RNasin inhibitor (Promega Corp., Madison, WI); $10 \mathrm{U}$ of Avian myeloblastosis virus reverse transcriptase (AMV RT; M5101, Promega Corp.); and 2.5 U of AmpliTaq (DNA polymerase, N801-0060; Perkin-Elmer, Boston). The thermal cycle conditions were $45^{\circ} \mathrm{C}$ for $60 \mathrm{~min}$; $92^{\circ} \mathrm{C}$ for

\section{CN 405 5'-GCCTTAAGGGTCGTTAATTG-3'}

\section{CN 408 5'-GATTATATCACCCACGTTCACG-3'}

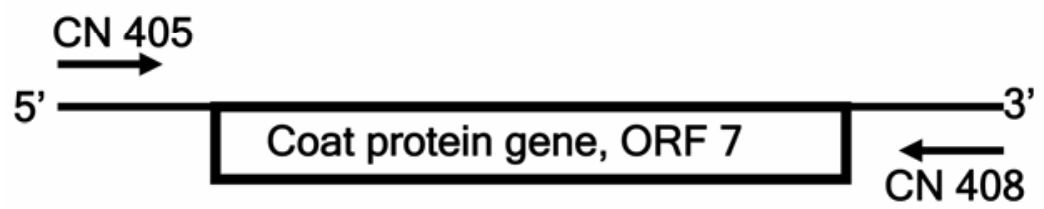

Fig. 1. Citrus tristeza virus (CTV) primers; sequences and approximate position relative to the coat protein gene to give an estimated polymerase chain reaction product size of approximately $792 \mathrm{bp}$, corresponding to positions 16,057 to 16,848 bp on the SY568 CTV genome; ORF = open reading frame.
2 min; 30 cycles of $92^{\circ} \mathrm{C}$ for $30 \mathrm{~s}, 50^{\circ} \mathrm{C}$ for $45 \mathrm{~s}$, and $72^{\circ} \mathrm{C}$ for $1 \mathrm{~min}$; then extension for $10 \mathrm{~min}$ at $72^{\circ} \mathrm{C}$ and hold at $4^{\circ} \mathrm{C}$.

Reverse transcription for the synthesis of first-strand cDNA in the two-step RTPCR method was made using $3 \mu \mathrm{g}$ of total RNA or $15 \mu$ of a dsRNA-enriched sample from each CTV isolate, and the RNA was heated for $15 \mathrm{~min}$ at $65^{\circ} \mathrm{C}, 10 \mathrm{~min}$ at $55^{\circ} \mathrm{C}$, and then $5 \mathrm{~min}$ at room temperature. Final volume of the reaction mix was $25 \mu \mathrm{l}$, and this contained 50 pmoles of primer $\mathrm{CN}$ 408; $50 \mathrm{mM}$ Tris- $\mathrm{HCl}, \mathrm{pH} 8.3$, at $25^{\circ} \mathrm{C} ; 50$ $\mathrm{mM} \mathrm{KCl} ; 10 \mathrm{mM} \mathrm{MgCl}_{2} ; 0.5 \mathrm{mM}$ spermidine; $10 \mathrm{mM}$ DTT; $0.2 \mathrm{mM}$ each dATP, dCTP, dGTP, and dTTP; 5 U of RNasin; and $10 \mathrm{U}$ of AMV RT. The contents were gently mixed, then incubated at $47^{\circ} \mathrm{C}$ for 1 $\mathrm{h}$, after which $12 \mu \mathrm{l}$ of nuclease-free water was added and the cDNA stored at $-20^{\circ} \mathrm{C}$. Each of the two-step PCR reactions contained $5 \mu \mathrm{l}$ of the cDNA reaction, 100 pmoles of $\mathrm{CN} 405$ and $\mathrm{CN} 408,10 \mathrm{mM}$ Tris- $\mathrm{HCl}, \mathrm{pH} 8.3$, at $25^{\circ} \mathrm{C}, 50 \mathrm{mM} \mathrm{KCl}$, $2.5 \mathrm{mM} \mathrm{MgCl}_{2}$, and $2.5 \mathrm{U}$ of AmpliTaq. PCR conditions were similar to the description of the one-step RT-PCR but the first incubation cycle of $45^{\circ} \mathrm{C}$ for $60 \mathrm{~min}$ was omitted. RNA samples were extracted from virus-free citrus plants and citrus plants infected with Citrus tatterleaf virus (genus: Capillovirus, species: Apple stem grooving virus: isolate: Citrus tatterleaf virus), and these samples were included in all tests as checks. Nuclease-free water was included instead of the RNA as an additional RT-PCR control. PCR products $(5 \mu \mathrm{l})$ were analyzed by gel electrophoresis through $1.2 \%$ agarose (Gibco-BRL) in Tris-acetate-EDTA (TAE) buffer $(40 \mathrm{mM}$ Tris-acetate, $\mathrm{pH}$ 8.0, $1 \mathrm{mM}$ EDTA), stained with ethidium bromide $(0.5 \mu \mathrm{g} / \mathrm{ml})$, and photographed under UV light.

Hybridization to CTV CPG strainspecific oligonucleotides. Seven of the Texas CTV isolates evaluated by the citrus host-range indexing were analyzed using CTV strain-group-specific probes (SGSP) developed by Niblett and co-workers (26; US patent no. 6,140,046). Subsamples of CPG cDNA generated by the RT-PCR reactions from the $\mathrm{CTV}$-infected samples were vacuum blotted onto replicate nylon membranes (43). CTV CPG-specific oligonucleotide probes then were hybridized to the membranes (US patent no. $6,140,046)$. Hybridization reactions were visually assessed for intensity on a T-to-5 rating, where $\mathrm{T}=$ trace, $1=$ weak hybridization, and $5=$ strong hybridization for each probe reaction. The chemiluminescent detection used the CDP Star streptavidin-alkaline phosphatase conjugate (Boehringer Mannheim [Roche Diagnostics], Indianapolis, IN). Probe and uninfected controls were included on each membrane.

Single-stranded conformation polymorphism. Amplified PCR product $(1 \mu \mathrm{l})$ was mixed with $9 \mu$ of denaturing solution 
(95\% high-performance liquid chromatography-grade formamide, $20 \mathrm{mM}$ EDTA, $\mathrm{pH} 8.0,0.05 \%$ bromophenol blue, and $0.05 \%$ xylene-cyanol), heated for $10 \mathrm{~min}$ at $99^{\circ} \mathrm{C}$, and immediately chilled on ice. The DNA strands were separated by electrophoresis in a nondenaturing polyacrylamide ( $8 \%$ acrylamide) using TBE (1×) as electrophoresis buffer and a constant voltage of $200 \mathrm{~V}$ for $3 \mathrm{~h}$ at $4^{\circ} \mathrm{C}$ $(40,42)$. Gels were stained with 1:10,000 diluted SYBR Gold (Molecular Probes, Eugene, OR) for $10 \mathrm{~min}$, destained for 10 min, and then photographed under UV light.

\section{RESULTS}

Biological indexing. In the first biological indexing test, all CTV isolates produced leaf vein flecking in Mexican lime 3 months after inoculation. With the most severe isolates, there were many leaf flecks in every leaf; whereas, with other CTV sources, there were one or two flecks on one or two leaves compared with the uninoculated plants. Leaf cupping was noted from some CTV isolates, but this symptom was not rated because it is not diagnostic for CTV alone. Some CTV isolates produced numerous stem pits in Mexican lime, whereas the milder CTV isolates had minor stem pitting. CTV isolates inoculated onto the sweet orange grafted to sour (SW/SO) caused stunting of the scions relative to controls and, in the most severe cases, a brown smear under the bark on the sour orange side of the bud union was present where the scions were undergoing senescence and typical CTV decline. Duncan grapefruit stunting symptoms ranged from severe to very mild compared with the uninoculated controls. Madam Vinous sweet orange seedlings were stunted with or without stem pitting compared with the uninoculated controls. Distinct chlorosis usually associated with the seedling yellows symptoms (sour orange or grapefruit seedlings) was not observed. The biological indexing data from indexing experiment 1 and the corresponding serological data are summarized in Table 1. Only 2 of 15 CTV isolates (H10 and H11) were mild in symptoms or produced CTV symptoms only in Mexican lime. Six of the CTV isolates produced symptoms in every indicator host. The most severe CTV isolate was H33, which originated from a Meyer lemon. Using the biotype rating method (18), most CTV isolates were in biotype groups IX or X or contained either two or three of the severe groups of CTV symptoms. Of the six CTV isolates which were inoculated onto Texas commercial scion cultivars, two produced stem pitting symptoms only on sweet orange, one isolate produced stem pitting symptoms on grapefruit scions only, and three isolates produced stem pitting on both sweet orange and grapefruit scions (Table 2). The most severe CTV isolates on the Texas commercial cultivars were from Meyer lemon. Generally, the commercial cultivars were more susceptible to CTV with greater stem pitting and reduction in height than the Pineapple sweet orange and Duncan grapefruit indicator plants.

Experiment 2 bioindex compared four Texas CTV isolates to six control BARC CTV isolates (Table 3). Three of the Texas isolates produced disease symptoms in all indicator hosts, whereas one Texas CTV isolate produced symptoms only in Mexican lime and sweet orange on sour orange. The BARC CTV isolates were ranked according to the cumulative total of all the mean relative disease assessments in de-

Table 2. Indexing of six Texas Citrus tristeza virus (CTV) isolates in experiment 1 with four Texas commercial cultivars on sour orange rootstocks ${ }^{\mathrm{a}}$

\begin{tabular}{lcccc}
\hline CTV source & $\begin{array}{c}\text { Rio Red GFT } \\
\mathbf{R} \times \mathbf{4}\end{array}$ & $\begin{array}{c}\text { Star Ruby GFT } \\
\mathbf{R} \times \mathbf{4}\end{array}$ & $\begin{array}{c}\text { Marrs SW } \\
\mathbf{R} \times \mathbf{5}\end{array}$ & $\begin{array}{c}\mathbf{N}-33 \mathbf{S W} \\
\mathbf{R} \times \mathbf{5}\end{array}$ \\
\hline H8 & 0 & 0 & 2 & 4 \\
H9 & 3 & 2 & 1 & 1 \\
H19 & 4 & 1 & 0 & 0 \\
H41 & 2 & 2 & 3 & 6 \\
H47 & 6 & 4 & 4 & 4 \\
H48 & 0 & 0 & 3 & 2 \\
\hline
\end{tabular}

${ }^{a}$ Mean relative weighted indices in commercial citrus cultivars: GFT $=$ grapefruit (Citrus $\times$ paradisi) grafted to sour orange (C. aurantium) rootstock and $\mathrm{SW}=$ sweet orange $(C$. sinensis $)$ grafted to sour orange rootstock. Each number represents the relative mean assessment $(\mathrm{R})$ of symptoms on a 0 -to-3 scale where $0=$ no symptoms and $3=$ severe symptoms, with extrapolations, multiplied by an economic weighting factor $(\mathrm{R} \times 4$ for GFT and $\mathrm{R} \times 5$ for $\mathrm{SW})$ for each particular citrus species combination (adapted after 12).

Table 1. Citrus indexing and serology for Texas Citrus tristeza virus (CTV) isolates in experiment 1

\begin{tabular}{|c|c|c|c|c|c|c|c|c|c|}
\hline \multirow[b]{2}{*}{ CTV source } & \multirow[b]{2}{*}{ Location, tissue ${ }^{c}$} & \multicolumn{6}{|c|}{ Citrus indexing ${ }^{\mathrm{a}}$} & \multicolumn{2}{|c|}{ Serology ${ }^{b}$} \\
\hline & & ML R $\times 1$ & SW/SO R $\times 2$ & SO R $\times 3$ & DGFT $R \times 4$ & MV R $\times 5$ & CUM & POLY & MCA-13 \\
\hline H6 & EAST, Nippon orangequat & 1 & NT & 0 & 0 & 1 & 2 & + & + \\
\hline H8 & LRGV, grapefruit & 3 & 0 & 0 & 0 & 6 & 9 & + & - \\
\hline H9 & LRGV, Bell tangerine & 2 & 2 & 1 & 1 & 2 & 8 & + & - \\
\hline $\mathrm{H} 10$ & LRGV, Cara Cara sweet orange & 1 & 0 & 0 & 0 & 0 & 1 & + & - \\
\hline H11 & LRGV, ? & 1 & NT & 0 & 0 & 0 & 1 & + & - \\
\hline H12 & LRGV, variegated lemon & 1 & NT & 0 & 0 & 2 & 3 & + & - \\
\hline H19 & EAST, Armstrong early satsuma & 2 & NT & 1 & 0 & 0 & 3 & + & + \\
\hline $\mathrm{H} 29$ & LRGV, citrangeuma & 1 & NT & 1 & 2 & 6 & 10 & + & - \\
\hline $\mathrm{H} 31$ & LRGV, Thornton tangelo & 1 & NT & 1 & 1 & 2 & 5 & + & - \\
\hline $\mathrm{H} 41$ & LRGV, Meyer lemon & 3 & 1 & 2 & 6 & 4 & 15 & + & + \\
\hline $\mathrm{H} 42$ & EAST, satsuma & 2 & NT & 2 & 2 & 0 & 6 & + & NT \\
\hline $\mathrm{H} 45$ & EAST, Armstrong early satsuma & 1 & NT & 1 & 2 & 1 & 5 & + & - \\
\hline $\mathrm{H} 47$ & LRGV, Meyer lemon & 1 & 1 & 1 & 4 & 1 & 7 & + & + \\
\hline $\mathrm{H} 48$ & EAST, Hamlin sweet orange & 1 & NT & 2 & 0 & 5 & 8 & + & - \\
\hline $\mathrm{H} 49$ & LRGV, Meyer lemon & 1 & NT & 2 & 3 & 0 & 6 & + & - \\
\hline
\end{tabular}

${ }^{a}$ Citrus indexing: Mean relative weighted indices in citrus cultivars. ML $=$ Mexican lime $(C$. aurantifolia $)$, SW/SO = pineapple sweet orange grafted to sour orange, $\mathrm{DGFT}=$ Duncan grapefruit $(C . \times$ paradisi $), \mathrm{SO}=$ sour orange $(C$. aurantium $), \mathrm{MV}=$ Madam Vinous sweet orange $(C$. sinensis $), \mathrm{CUM}=\mathrm{cumula}-$ tive total of all mean relative weighted indices for the particular CTV source. Each number represents the relative mean assessment (R) of symptoms on a 0 -to- 3 scale where $0=$ no symptoms and $3=$ severe symptoms, with extrapolations, multiplied by a weighting factor ( $\mathrm{R} \times 1$ for ML, for example) for each particular citrus cultivar or species combination (12), and NT $=$ not tested.

b Serology: Poly = using polyclonal coat protein CTV antisera in a double-antibody sandwich enzyme-linked immunosorbent assay format, MCA-13 (32) = using CTV MCA-13 in an immunoblot format, $+=$ reaction with antibodies, $-=$ no reaction with antibodies, and NT $=$ not tested. All serology tests were repeated three times.

${ }^{\mathrm{c}}$ LRGV $=$ collected in the Lower Rio Grande Valley and EAST $=$ collected in East Texas. Tissues: Nippon orangequat (Fortunella crassifolia $\times$ Citrus unshiu), grapefruit $(C . \times$ paradisi $)$, Bell tangerine (C. reticulata), sweet orange $(C$. sinensis $)$, variegated lemon $(C$. limon), satsuma $(C$. unshiu $)$, citrangeuma $(($ Poncirus trifoliata $\times$ C. sinensis $) \times$ C. unshiu? $)$, Thornton tangelo $($ C. reticulata $\times$ C. $\times$ paradisi $)$, and Meyer lemon $($ C. meyeri $)$. 
scending order of severity, as follows: B6, B28, B384, B4, B5, and B2. B6 also produced leaf corking on sweet orange and severe dieback of grapefruit seedlings. B2 produced the mildest CTV symptoms observed, with only one or two inoculated Mexican lime leaves showing occasional leaf vein flecking. H33 was used in experiment 2 and ranked as the most severe Texas CTV isolate to date, with a cumulative index of 26. This isolate produced all of the severity components of stem pitting on sweet orange and grapefruit, sweet on sour decline, and seedling yellows in sour orange and grapefruit seedlings.

Several CTV isolates (H33, H47, H41, and H49) induced stem pitting on sour orange rootstock distinct from the classical decline symptom of honeycombing (7). The Capão Bonito CTV isolate from Brazil another infectious disease of citrus, cristacortis, also can cause this symptom (35). H33 also was indexed in duplicate for cristacortis using virus-free Orlando tangelo $(C$. reticulata $\times C$. $\times$ paradisi $)$ grafted to sour orange seedlings during the period of the tests, and no young tangelo leaf chlorosis was observed. CTV could be detected by ELISA in all inoculated plants but not in the uninoculated checks.

Serological and RNA-blot analyses. All CTV isolates from their original source plant tissues consistently reacted with CTV $\mathrm{CP}$ polyclonal antibodies over three assessment periods (Table 1; serology). In tissue blots using MAb MCA-13, four CTV isolates consistently reacted, suggesting that $\mathrm{H} 6, \mathrm{H} 19, \mathrm{H} 41$, and $\mathrm{H} 7$ contain declineinducing CTV strains. Some CTV isolates (Table 1) gave sweet on sour orange decline-type symptoms or stem pitting symptoms, but they did not react with MCA-13. Northern hybridizations using total RNA from each CTV source probed with the $3^{\prime}$ causes stem pitting on sour orange and

end of the SY568 CTV genome also confirmed that the same plants contained CTV.

cDNA production and CTV CP straingroup probes. Using $\mathrm{CTV} \mathrm{CP}$-specific primers, an RT-PCR product of the approximate predicted size (792 bp) was amplified from all CTV isolates tested. In every test, the corresponding probe control sample hybridized with the appropriate probe, and non-CTV samples did not hybridize. The blots for probes I, II, and V showed a wide variety of intensities of hybridization. The visual assessments appeared to be associated with certain probes and CTV isolate biological activity. Probes II and IV did not hybridize to any of the CTV isolates tested (Table 4).

Single-stranded conformational polymorphism analyses. The single-stranded conformational polymorphism (SSCP) profiles for the PCR-amplified CP gene product of some of the CTV isolates are shown in Figure 2, and all the results are summarized in Table 4. In some isolates, two or three DNA products were delimited; however, in the greater majority, four or six products were observed with similar staining intensity. Some of the banding patterns were indistinguishable. For instance, H9, H10, H11, and H12 all separated three products at similar distances to each other, although the citrus-indexing data suggest different biology of the CTV source. There were no associations between geographical origin or cultivar type of the CTV sources and SSCP profile. Meyer lemon tissue samples generally had similar profiles, even though individual samples were collected in different geographic regions and at different times.

\section{DISCUSSION}

Compared with the BARC CTV control isolates indexed under our conditions, the most severe Texas CTV isolate, H33, ranks

Table 3. Summary of citrus indexing of four Texas Citrus tristeza virus (CTV) isolates compared with six reference isolates from the World CTV Collection in experiment $2^{\mathrm{a}}$

\begin{tabular}{lcccccc}
\hline CTV source $^{\mathbf{b}}$ & ML R $\times \mathbf{1}$ & SW/SO R $\times \mathbf{2}$ & $\mathbf{S O ~ R} \times \mathbf{3}$ & $\mathbf{D G F T ~ R \times 4}$ & $\mathbf{M V ~ R} \times \mathbf{5}$ & $\mathbf{C U M}$ \\
\hline H1 1 & 1 & $2 ?$ & 0 & $0 ?$ & 0 & $3 ?$ \\
H29 & 1 & 2 & 3 & 4 & 5 & 15 \\
H33 & 3 & 4 & 6 & 8 & 5 & 26 \\
H41 & 2 & 2 & 6 & 4 & 5 & 19 \\
B2 & 1 & 0 & 0 & 0 & 0 & 1 \\
B4 & 2 & 4 & 0 & 4 & 5 & 15 \\
B5 & 1 & 2 & 0 & 0 & 0 & 3 \\
B6 & 3 & 6 & 6 & 12 & 10 & 37 \\
B28 & 2 & 4 & 9 & 12 & 5 & 32 \\
B384 & 2 & 6 & 3 & 8 & 0 & 19 \\
\hline
\end{tabular}

${ }^{a}$ Citrus indexing: mean relative weighted indices in citrus cultivars. ML = Mexican lime (Citrus aurantifolia $),$ DGFT $=$ Duncan grapefruit $(C . \times$ paradisi $), \mathrm{SW} / \mathrm{SO}=$ pineapple sweet orange $(C$. sinensis) grafted to sour orange $(C$. aurantium) rootstock, $\mathrm{SO}=$ sour orange, $\mathrm{MV}=$ Madam Vinous sweet orange, CUM = cumulative total of all mean relative weighted indices for the particular CTV source; reactions do not fit with any known isolate, symptoms very slow to develop and always in the lowest reaction group. Each number represents the relative mean assessment (R) of symptoms on a 0-to-3 scale where $0=$ no symptoms and $3=$ severe symptoms, with extrapolations, multiplied by a weighting factor $(\mathrm{R} \times 1$ for $\mathrm{ML}$, for example) for each particular citrus cultivar or species combination (12).

${ }^{b}$ CTV isolates: $\mathrm{H}$ prefix refer to Texas CTV isolate H33; this derives from the same original Meyer lemon tree as H41. B prefix refers to CTV isolates obtained from the United States Department of Agriculture, Beltsville, MD, which are used in this experiment to compare the severity of CTV with these isolates under Texas conditions. less severe than $\mathrm{B} 6$ and $\mathrm{B} 24$ but more severe than B384, B4, B5, and B2, clearly placing it among severe isolates.

Five Texas CTV isolates contained the full complement of severe CTV components of SW/SO decline, seedling yellows and stem pitting in grapefruit, seedling yellows symptoms in sour orange seedlings, and stem pitting on sweet orange, placing these isolates in the most severe biotype group, $\mathrm{X}$ (18). The majority of CTV isolates from Texas contained at least two groups of economically severe CTV symptoms, being categorized in biotypes IX or X. When collecting CTV isolates for this biological testing, it was difficult to find isolates from the Lower Rio Grande Valley commercial CTV sources because the CTV incidence is extremely low (45). Three of the CTV isolates, H8, H10, and $\mathrm{H} 11$, originated from commercial sources in the Lower Rio Grande Valley. H10 and H11 produced the mildest CTV symptoms in the biological indexing. The majority of the CTV isolates were collected from noncommercial citrus, and these isolates harbored the most damaging CTV biotype, X. The majority of the CTV isolates used in these tests essentially were field CTV isolates, with no subisolation or passaging in planta.

In the biological tests on Texas commercial scions and six Texas CTV isolates, CTV symptoms were more severe than symptoms produced in the respective standard index citrus species. Stem pitting symptoms were more severe in the red grapefruit scions (more pits per stem surface area), as reported elsewhere (20), and the sweet on sour orange decline symptom was induced in a shorter time.

The serological methods used in these tests were effective at identifying CTV and providing information in the shortest time for relatively little expense. MCA-13 gave an indication of the presence of CTV causing SW/SO decline, similar to other, earlier reports $(31,32)$. MCA-13 also reacted with one Texas non-CTV-decline isolate, and other reports suggest that MCA-13 cannot detect all stem-pitting CTV isolates. Sequencing data is still needed on

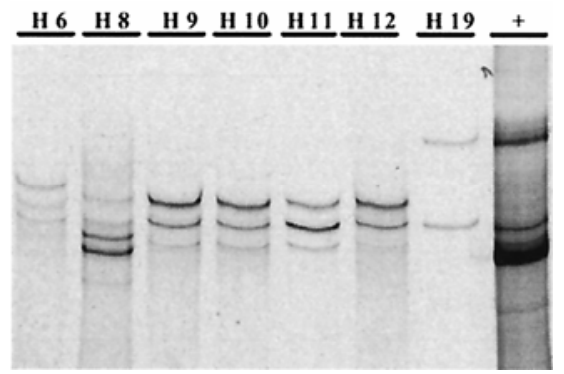

Fig. 2. Single-strand conformational polymorphism analyses. Citrus tristeza virus (CTV) isolate coat protein $(\mathrm{CP})$ cDNAs were denatured and separated by polyacrylamide gel electrophoresis; $\mathrm{H}=$ prefix for Texas isolate code (see text) and $+=$ cDNA amplified from a plasmid containing CTV T36 CP gene. 
these CTV isolates. If such nondecline activity is common, MCA-13 may not be useful to differentiate between destructive and nondestructive CTV isolates in sour orange in Texas. However, this would be the fastest method available for identification, should there be an urgent need to identify severe CTV sources over the commercial citrus-growing region.

The Florida CTV SGSP gave good indications of certain severe symptoms, with sweet on sour orange declines and grapefruit stem pitting being the most reliably predicted. Probe I gave the best all-round performance at prediction of all types of severe CTV symptoms. Probe I was developed using CTV isolates T36, T66, 202B1, and T10, and PB53DRF1, a grapefruit stem-pitting CTV isolate from Australia. CTV T36 and T66 are Florida isolates causing decline of scions on sour orange rootstock (30). Florida isolate 202B-1 causes decline, seedling yellows, and grapefruit stem pitting. A drawback to using a hybridization technique would be variability depending on the stringency of the hybridization conditions. Thus, the test might be highly subjective if carried out by different laboratories.

SSCP profiles of the CTV CP gene were diverse and similar to that obtained by other workers (40). Usually two to six products are obtained when using cDNA generated to the CTV CP gene. The procedures are relatively robust and easy to perform, and banding patterns were reproducible. The mildest CTV isolate, H10 (biotype I), showed three products and the severe isolates sometimes showed two or four or more products (all biotype $\mathrm{X}$ isolates). Multiple DNA products in the SSCP profile reflect the sequence variants present in the RNA population down to se- quence variants forming $10 \%$ of the RNA population $(41,42)$. The technique is useful to study the dominant population components; for instance, in initial selection of cross-protection CTV isolates, monitoring the process of cross-protection (42), or virus passaging experiments. The phenomenon of genomic RNA (gRNA) "clusters" around a sequence variant is a wellestablished aspect of positive-stranded RNA plant virus populations in nature $(15,39)$ and may account for the biological nature of certain CTV isolates. Similar observations have been made by other workers when analyzing the p18 gene or the 5' untranslated region of various CTV isolates (3). In such studies, it was found that mildly pathogenic CTV isolates contained one sequence type whereas severely pathogenic isolates contained two or three sequence types. There was no clear-cut association between product number and biological activity of the Texas CTV isolates in this study. Meyer lemon CTV sources all had four products, even though samples were collected at different times and geographic regions, and this might be more indicative of the clonal nature of Meyer lemon trees, because some propagations in the continental United States can be traced to one introduction in 1908 (22), but this also may indicate that the CTV population and Meyer lemon combination could be stable over time.

Six full-length CTV sequences are now available in GenBank and each isolate represents different geographic areas of origin or different biological activities $(2,13,17,21,46,47$; GenBank accession no. AY340974). The search for genetic markers for the different symptoms can be done across the whole genome now using the full-length sequence data and various algo- rithms at different settings to first search for regions of the genome with predicted low, medium, and high nucleotide mutation rates $(24,25)$. Such regions can be sampled by RT-PCR, with polymorphisms detected, and a model or models predicted. Many field CTV isolates then could be subjected to the tests and phenotyped so that the proposed models may be verified or modified. The intricacies of the behavior between different RNAs of the CTV population within one tree relates to symptom development and severity because making subisolates by grafting or aphid transmission separates some of the variety of CTV biology in citrus plants $(1,36)$. Thus, more CTV sequencing data from field isolates likely are needed in order to sample the biological activity of CTV in field trees.

Reservoirs of damaging CTV isolates exist mainly within dooryard citrus, and surveys indicate greater CTV incidence in east Texas (45). The majority of commercial citrus in Texas is on CTV-sensitive sour orange rootstock; this citrus has low CTV incidence at the moment. Implications from this work are that the situation likely will change when the BrCA arrives. Texas is the "front line" in the United States for arrival of the BrCA through Mexico, although it also may enter along the Gulf Coast from Florida. When the BrCA arrives, the damaging Texas CTV isolates likely will get distributed from dooryard plants to commercial citrus.

CTV management strategies include eradication, quarantine and certification programs, use of resistant or tolerant rootstocks, or cross-protection with mild isolates (34). Deployment of each strategy is highly dependent upon the incidence and severity of CTV present in a region; therefore, practices often change over time. Se-

Table 4. Summary of the Texas Citrus tristeza virus (CTV) isolate Florida strain-group-specific probe (SGSP) hybridizations and single-stranded conformational polymorphism (SSCP) analyses

\begin{tabular}{|c|c|c|c|c|c|c|c|c|c|}
\hline \multirow[b]{2}{*}{ CTV source } & \multirow[b]{2}{*}{ Location, tissue $^{b}$} & \multicolumn{7}{|c|}{ Florida SGSPa } & \multirow{2}{*}{$\begin{array}{c}\text { SSCP } \\
\text { Products }\end{array}$} \\
\hline & & $\mathbf{0}$ & $\mathbf{I}$ & II & III & IV & $\mathbf{V}$ & VIII & \\
\hline H6 & EAST, Nippon orangequat & 4 & 3 & 0 & 1 & 0 & 3 & 5 & 4 \\
\hline H8 & LRGV, grapefruit & 1 & 1 & 0 & 2 & 0 & 1 & 5 & 4 \\
\hline H9 & LRGV, Bell tangerine & NT & $\ldots$ & $\ldots$ & $\ldots$ & $\ldots$ & $\ldots$ & $\ldots$ & 4 \\
\hline H10 & LRGV, Cara Cara sweet orange & 3 & 3 & 0 & 0 & 0 & 0 & 5 & 4 \\
\hline H11 & LRGV, ? & NT & $\ldots$ & $\ldots$ & $\ldots$ & $\ldots$ & $\ldots$ & $\ldots$ & 4 \\
\hline H12 & LRGV, variegated lemon & 3 & 3 & 0 & 0 & 0 & 1 & 5 & 2 \\
\hline H19 & EAST, Armstrong early satsuma & NT & $\ldots$ & $\ldots$ & $\ldots$ & $\ldots$ & $\ldots$ & $\ldots$ & 4 \\
\hline $\mathrm{H} 29$ & LRGV, citrangeuma & 1 & 1 & 0 & $\mathrm{~T}$ & 0 & 0 & 3 & 4 \\
\hline H31 & LRGV, Thornton tangelo & $\mathrm{T}$ & $\mathrm{T}$ & 0 & 0 & 0 & 0 & 2 & 4 \\
\hline $\mathrm{H} 41$ & LRGV, Meyer lemon & 1 & 1 & 0 & 1 & 0 & 4 & 4 & 4 \\
\hline $\mathrm{H} 42$ & EAST, satsuma & NT & $\ldots$ & $\ldots$ & $\ldots$ & $\ldots$ & $\ldots$ & $\ldots$ & 4 \\
\hline H45 & EAST, Armstrong early satsuma & NT & $\ldots$ & $\ldots$ & $\ldots$ & $\ldots$ & $\ldots$ & $\ldots$ & 4 \\
\hline H47 & LRGV, Meyer lemon & 1 & $\mathrm{~T}$ & 0 & $\mathrm{~T}$ & 0 & 5 & 4 & 4 \\
\hline $\mathrm{H} 48$ & EAST, Hamlin sweet orange & NT & $\ldots$ & $\ldots$ & $\ldots$ & $\ldots$ & $\ldots$ & $\ldots$ & 4 \\
\hline $\mathrm{H} 49$ & LRGV, Meyer lemon & 1 & $\mathrm{~T}$ & 0 & 2 & 0 & 4 & 2 & 4 \\
\hline
\end{tabular}

${ }^{a}$ Florida SGSP hybridizations: 0, I, II, III, IV, V, and VIII are the different oligonucleotide probes generated to the CTV coat protein (CP) gene and hybridized to cDNA from each source; NT = not tested. Hybridization assessments were made on a visual T-to- 5 scale for the intensity of the different samples, where $\mathrm{T}=$ trace, $0=$ no hybridization, $5=$ strong hybridization (26), and NT = not tested. SSCP: number of products obtained during SSCP analyses of the CTV CP gene; all SSCP tests were repeated three times.

${ }^{\mathrm{b}}$ Nippon orangequat (Fortunella crassifolia $\times$ Citrus unshiu), grapefruit $(C . \times$ paradisi), Bell tangerine $(C$. reticulata), sweet orange $(C$. sinensis), variegated lemon $($ C. limon), satsuma (C. unshiu), citrangeuma ((Poncirus trifoliata $\times$ C. sinensis $) \times C$. unshiu?), Thornton tangelo $($ C. reticulata $\times$ C. $\times$ paradisi $)$, and Meyer lemon (C. meyeri). 
verity typing using the standard set of citrus indicators and determining CTV biotype category or cumulative index can be done only on small groups of samples. This process is subjective, lengthy, and requires skill and knowledge of each citrus species or cultivar and the many symptoms which may be induced by CTV. A rapid, reliable test to differentiate the mild from the severe forms of CTV with great reliability still eludes the citrus-indexing process.

\section{ACKNOWLEDGMENTS}

We thank R. F. Lee for the gift of polyclonal CTV antibodies and advice throughout the work, C. N. Niblett for the Florida probe analyses, and M. G. H. Dekkers for technical assistance with the Florida probe analyses.

\section{LITERATURE CITED}

1. Albiach-Martí, M. R., Guerri, J., Hermoso de Mendoza, A., Laigret, F., Ballester-Olmos, J. F., and Moreno, P. 2000. Aphid transmission alters the genomic and defective RNA populations of Citrus tristeza virus isolates. Phytopathology 90:134-138.

2. Albiach-Martí, M. R., Mawassi, M., Gowda, S., Satyanarayana, T., Hilf, M. E., Shanker, E., Almira, E. C., Vives, M. C., López, C., Guerri, J., Flores, R., Moreno, P., Garnsey, S. M., and Dawson, W. O. 2000. Sequences of Citrus tristeza virus separated in time and space are essentially identical. J. Virol. 74:6856-6865.

3. Ayllón, M. A., López, C., Navas-Castillo, J., Garnsey, S. M., Guerri, J., Flores, R., and Moreno, P. 2001. Polymorphism of the 5' terminal region of Citrus tristeza virus (CTV) RNA: Incidence of three sequence types in isolates of different origin and pathogenicity. Arch. Virol. 146:27-40.

4. Bar-Joseph, M., and Lee, R. F. 1989. Citrus tristeza virus. In: Description of Plant Viruses No. 353 (No. 33 revised). Commonwealth Mycological Institute/Association of Applied Biology, Kew, Surrey, UK.

5. Broadbent, P., Dephoff, C. M., Franks, N., Gillings, M., and Industo, J. 1995. Preimmunization of grapefruit with a mild protective isolate of Citrus tristeza in Australia. Pages 163-168 in: Proc. 3rd Int. Workshop on Citrus tristeza virus and Brown citrus aphid in Central America and the Caribbean. R. Lee, M. RochaPeña, C. L. Niblett, F. Ochoa, S. M. Garnsey, R. K. Yokomi, and R. Lastra, eds. FAO-USDAOICD-University of Florida, Lake Alfred.

6. Church, G. M., and Gilbert, W. 1984. Genomic sequencing. Proc. Natl. Acad. Sci. USA 81:1991-1995.

7. Cohen, M., and Knorr, L. C. 1954. Present status of tristeza in Florida. Proc. Fla. State Hortic. Soc. 66:20-22.

8. Davis, R. M., Sauls, J. W., and Wilhite, H. S. 1984. Survey for tristeza in Texas citrus. J. Rio Grande Valley Hortic. Soc. 37:61-64.

9. Domingo, E., Holland, J., Biebricher, C., and Eigen, M. 1995. Quasi-species: the concept and the word. Pages 181-191 in: Molecular Basis of Viral Evolution. A. J. Gibbs, C. H. Calisher, and F. Garcia-Arenal, eds. Cambridge University Press, Cambridge.

10. Garnsey, S. M., and Cambra, M. 1991. Enzyme-linked immunosorbent assays for citrus pathogens. Pages 193-216 in: Graft Transmissible Diseases of Citrus. Handbook for Detection and Diagnosis. C. N. Roistacher, ed. Food and Agriculture Organization of the United Nations, Rome.

11. Garnsey, S. M., Civerolo, E. L., Gumpf, D. J., Yokomi, R. K., and Lee, R. F. 1991. Development of a worldwide collection of citrus tristeza isolates. Pages 113-120 in: Proc. 11th
Conf. Int. Organ. Citrus Virol. R. H. Brlansky, R. F. Lee, and L. W. Timmer, eds. IOCV, University of California, Riverside.

12. Garnsey, S. M., Gumpf, D. J., Roistacher, C. N., Civerolo, E. L., Lee, R. F., Yokomi, R. K., and Bar-Joseph, M. 1987. Toward a standardized evaluation of the biological properties of citrus tristeza virus. Phytophylactica 19:151-157.

13. Gede, S., Natsuaki, T., Terui, H., Kano, T., Ieki, H., and Okuda, S. 2001. Nucleotide sequence of Citrus tristeza virus seedling yellow isolate. J. Gen. Plant Pathol. 67:73-77.

14. Hardy, N. 1995. Brown citrus aphid found in Ft. Lauderdale. Citrus Ind. 76 (12):31.

15. Holmes, E. C. 2003. Molecular clocks and the puzzle of RNA virus origins. J. Virol. 77:38933897.

16. Kahlke, C. J., da Graça, J. V., Skaria, M., and Solís-Gracia, N. 2000. Texas virus-free Citrus Budwood Program developments. Proc. Int. Soc. Citricult. 5:452.

17. Karasev, A. V., Boyko, V. P., Gowda, S., Nikolaeva, O. V., Hilf, M. E., Koonin, E. V., Niblett, C. L., Cline, K., Gumpf, D. J., Lee, R. F., Garnsey, S. M., Lewandowski, D. J., and Dawson, W. O. 1995. Complete sequence of the citrus tristeza virus genome. Virology 208:511-520.

18. Lee, R. F., Baker, P. S., and Rocha-Peña, M. A. 1994. The Citrus tristeza virus (CTV). An Introduction to Current Priorities, with Special Reference to the Worsening Situation in Central America and the Caribbean. Int. Inst. Biological Control, Ascot, UK.

19. Malouf, W. 1959. Tristeza virus in Meyer lemon and other varieties in the Upper Gulf coast of Texas. J. Rio Grande Valley Hortic. Soc. 13:27-29.

20. Marais, L. J., and Breytenbach, J. H. J. 1996. The effect of tristeza stem pitting on the Star Ruby grapefruit industry in southern Africa. Proc. Int. Soc. Citricult. 1:357-365.

21. Mawassi, M., Gafny, R., Gagliardi, D., and Bar-Joseph, M. 1995. Populations of citrus tristeza virus contain smaller-than-full-length particles which encapsidate sub-genomic RNA molecules. J. Gen. Virol. 76:651-659.

22. McKee, R. 1926. Chinese dwarf Meyer lemon introduced. Pages 218-221 in: Yearbook of Agriculture. United States Department of Agriculture, Washington, DC

23. Michaud, J. P., and Alvarez, R. 2000. First collection of brown citrus aphid, Toxoptera citricida (Homoptera:Aphididae) in Quintana Roo, Mexico. Fla. Entomol. 83:357-358.

24. Moonan, F., and Mirkov, T. E. 2002. Analyses of genotypic diversity among North, South, and Central American isolates of Sugarcane yellow leaf virus: evidence for Colombian origins and for intraspecific spatial phylogenetic variation. J. Virol. 76:1339-1348.

25. Moonan, F., Molina, J., and Mirkov, T. E. 2000. Sugarcane yellow leaf virus: an emerging virus that has evolved by recombination between luteoviral and poleroviral ancestors. Virology 269:156-171.

26. Niblett, C. N., Genc, H., Cevik, B., Halbert, S., Brown, L., Nolasco, G., Bonacalza, B., Manjunath, K. L., Febres, V. J., Pappu, H. R., and Lee, R. F. 2000. Progress on strain differentiation of Citrus tristeza virus and its application to the epidemiology of the citrus tristeza disease. Virus Res. 71:97-106.

27. Olson, E. O. 1955. A survey for tristeza virus in Texas citrus. J. Rio Grande Valley Hortic. Soc. 9:51-60.

28. Olson, E. O., and McDonald, J. R. 1954. Tristeza in satsuma varieties of Texas. Plant Dis. Rep. 38:439-441

29. Olson, E. O., and Sleeth, B. 1954. Tristeza virus carried by some Meyer lemon trees in south Texas. Pages 84-88 in: Proc. 8th Annu. Rio Grande Valley Hortic. Inst., Weslaco, TX.

30. Pappu, H., Pappu, S., Niblett, C., Lee, R., and Civerolo, E. 1993. Comparative sequence analysis of the coat proteins of biologically distinct Citrus tristeza closterovirus isolates. Virus Genes 7:255-264.

31. Permar, T. A., and Garnsey, S. M. 1991. Comparison of biological indexing and immunological assays for identifying severe Florida isolates of citrus tristeza virus. Pages 56-59 in: Proc. 11th Conf. Int. Organ. Citrus Virol. R. H. Brlansky, R. F. Lee, and L. W. Timmer, eds. IOCV, University of California, Riverside

32. Permar, T. A., Garnsey, S. M., Gumpf, D. J., and Lee, R. F. 1990. A monoclonal antibody that discriminates strains of citrus tristeza virus. Phytopathology 80:224-228.

33. Rocha-Peña, M., and Lee, R. F. 1991. Serological techniques for the detection of citrus tristeza virus. J. Virol. Methods 34:311-331.

34. Rocha-Peña, M. A., Niblett, C. L., Lee, R. F., Ochoa-Corona, F. M., Lastra, R., Garnsey, S. M., and Yokomi, R. K. 1995. CTV and its aphid vector Toxoptera citricida - threats to citrus production in the Caribbean and Central and North America. Plant Dis. 79:437-444.

35. Roistacher, C. N. 1991. Citrus tristeza virus. Pages 17-25 in: Graft-Transmissible Diseases of Citrus. Handbook for Detection and Diagnosis. Food and Agriculture Organization of the United Nations, Rome.

36. Roistacher, C. N., and Bar-Joseph, M. 1987. Transmission of citrus tristeza virus (CTV) by Aphis gossypii and by graft inoculation to and from Passiflora spp. Phytophylactica 19:179-182.

37. Roistacher, C. N., and Moreno, P. 1992. The worldwide threat from destructive isolates of citrus tristeza virus-a review. Pages 7-19 in Proc. 11th Conf. Int. Organ. Citrus Virol. R. H. Brlansky, R. F. Lee, and L. W. Timmer, eds. IOCV, University of California, Riverside.

38. Roistacher, C. N., Gumpf, D. G., Dodds, J. A., and Lee, R. F. 1991. The threat of "The citrus killer". Calif. Citrogr. 76 (10):4-12, 22

39. Roossinck, M. J. 1997. Mechanisms of plant virus evolution. Annu. Rev. Phytopathol. 35:191-209.

40. Rubio, L., Ayllón, M. A., Guerri, J., Pappu, H., Niblett, C. L., and Moreno, P. 1996. Differentiation of citrus tristeza closterovirus (CTV) isolates by single-strand conformation polymorphism analysis of the coat protein gene. Ann. Appl. Biol. 129:479-489.

41. Rubio, L., Allyón, M. A., Kong, P., Fernandez, A., Guerri, J., Moreno, P., and Falk, B. W. 2000. Evidence for mixed infections and recombination between Citrus tristeza virus isolates (Abstr.) Phytopathology 90:S67.

42. Sambade, A., Rubio, L., Garnsey, S. M., Costa, N., Müller, G. W., Peyrou, M., Guerri, J., and Moreno, P. 2002. Comparison of viral RNA populations of pathogenically distinct isolates of Citrus tristeza virus: application to monitoring cross-protection. Plant Pathol. 51:257-265.

43. Sambrook, J., Fritsch, E. F., and Maniatis, T. 1989. Molecular Cloning: A Laboratory Manual. Cold Spring Harbor Laboratory Press, Cold Spring Harbor, NY.

44. Skaria, M., Baker, J., Kahlke, C., Solís-Gracia, N., Roistacher, C. N., and da Graça, J. V. 1996. A virus-free citrus budwood program for Texas. Proc. Int. Soc. Citricult. 1:366-368.

45. Solís-Gracia, N., Kahlke, C. J., Herron, C. M., da Graça, J. V., Essau, K. L., Miao, H. Q., and Skaria, M. 2001. Surveys for Citrus tristeza virus in Texas 1991-2000. Subtrop. Plant Sci. 53:4-8.

46. Vives, M. C., Rubio, L., López, C., NavasCastillo, J., Albiach-Martí, M. R., Dawson, W. O., Guerri, J., Flores, R., and Moreno, P. 1999. The complete genome sequence of the major component of a mild citrus tristeza virus isolate. J. Gen. Virol. 80:811-816

47. Yang, Z. N., Matthews, D. M., Dodds, J. A., and Mirkov, T. E. 1999. Molecular characterization of an isolate of citrus tristeza virus that causes severe symptoms in sweet orange. Virus Genes 19:131-142. 